\title{
Local discoveries and technological relatedness: the role of MNEs, imports and domestic capabilities
}

\author{
Alessia Lo Turco ${ }^{* \dagger}$ and Daniela Maggioni** \\ *Department of Economics, Marche Polytechnic University, Piazzale Martelli Raffaele, 8, 60121 Ancona, \\ Italy \\ **Department of Economics, Ca' Foscari University of Venice, Dorsoduro, 3246, 30123 Venezia, Italy \\ †Correspondence to: email<a.loturco@univpm.it>
}

\begin{abstract}
We explore the role of intra- and extra-regional product-specific capabilities in the introduction of local discoveries — products new to the firm and to its local market—by Turkish manufacturing firms. We find that product discoveries in a NUTS3 region are favoured by their technological proximity to the product mix of co-located foreign firms. Proximity to co-located domestic firms and local imports does not play any role. The high intensity of local discoveries in novel and exclusive capabilities which foreign affiliates bring into the local economy drives our findings. Finally, we show that the importance of knowledge spilling from foreign affiliates depends on their insidership in the local market, on their product-specific knowledge advantage and on local firms' absorptive capacity.
\end{abstract}

Keywords: Firm product innovation, cognitive proximity, foreign affiliates, complexity, Turkey JEL classifications: F11, F14, D22, D80, N30

Date submitted: 4 October 2017 Editorial decision: 24 October 2018 Date accepted: 31 October 2018

\section{Introduction}

The introduction of new goods is an essential growth creating engine (Aghion and Howitt, 1998). The discovery of new production opportunities, though, is strictly dependent on prior knowledge, as agents only tend to recognise those opportunities that are related to capabilities and information they already possess (Shane, 2000). While in standard neoclassical models fundamental competencies needed to produce all existing goods are a common pool for all agents, in reality a large part of production-related knowledge is tacit. Despite the rapid spur of information and communication technologies that increasingly allow international technological transfers, the crucial difference between information and knowledge persists and the flow of tacit knowledge turns to be a key factor for developing and preserving successful firm routines at the basis of competitive advantages of countries and regions (Maskell and Malmberg, 1999; Gertler, 2003; Howells, 2012).

In this perspective, developing economies are hardly able to autonomously diversify and upgrade their production structure. Their capabilities endowments are often technologically distant from those required to produce the newest technology frontier goods and firms are embedded in a local economy made up of similarly poorly endowed 
firms. If knowledge does not freely flow across the borders, path dependence is then expected to sharpen the technological divide between the North and the South of the world.

In this paper, we investigate the role of related intra- and extra-regional knowledge in the evolution of domestic firms' product space within the Turkish manufacturing sector. As outcome of our empirical analysis, we consider a firm's probability to introduce a local discovery. We define a local discovery as any product that is new both to the firm and to the NUTS3 region(s) where the firm is located. We model a firm's probability to introduce a local discovery as dependent on the extent of technological proximity-measured à la Hidalgo et al. (2007) - to extra-regional knowledge embedded in the product basket of co-located foreign firms and in local imports and to intra-regional knowledge incorporated in the product mix of co-located domestic firms. Our work, thus, aims at shedding light on the key role of extra-regional sources of related product-specific knowledge for relaxing path dependence. While intraregional knowledge spilling from other domestic firms may be too cognitively proximate for allowing structural change (Grabher, 1993; Boschma, 2005; Morrison et al., 2013), extra-regional skills and competencies may be determinant for the introduction of local discoveries which are often intensive in exclusive capabilities and, thus, require original knowledge for their production (Boschma and Frenken, 2011). In particular, knowledge transferred by foreign multinational enterprises (MNEs) is expected to play the most prominent role in promoting the emergence of product discoveries by pioneer firms in the local economy. MNEs transfer knowledge to their affiliates, produce highly skill intensive goods, reduce the discovery costs of new production opportunities for their local suppliers and may stimulate innovation by domestic competitors (UNCTAD, 2003; Javorcik, 2008; Wang and Wu, 2016). Also, compared with product-specific external knowledge embedded in imports, knowledge transfers from MNEs' affiliates in the local market mainly occur through personal interactions and exchanges and, hence, have a higher chance to effectively turn into upgrading and catch-up (Lorenzen and Mudambi, 2013).

Our work is close to the recent literature on extra-regional knowledge flows transferred through international linkages (Boschma and Iammarino, 2009; Zhu et al., 2017), to the literature on knowledge creation in global pipelines (Bathelt et al., 2004; Morrison et al., 2013) and on the interaction of localised innovative activities of foreign owned and domestic firm (Wang and Wu, 2016; Wang and Guo, 2017). Finally, our analysis also complements the international business and economic geography streams of literature on the location strategies of MNEs and on their role as providers of knowledge through formal and informal vertical linkages in emerging and developing hosts (Kim, 1998; Markusen and Venables, 2000; Ernst and Kim, 2002; Cantwell and Iguchi, 2005; Jindra et al., 2009; Giroud et al., 2012).

Compared with the existing studies, we provide some original advances. First, we exploit the available fine disaggregation level of our data on the product mix of firms to identify local discoveries and, for the first time to our knowledge we, therefore, investigate the impact of technological relatedness to extra- and intra-regional knowledge on firms' probability to introduce a good that is new both to the firm and to its local market. Second, the relative role of product-specific-related local knowledge spilling from different extra-regional sources has never been investigated by the literature. More specifically, for the first time, we test the impact of product-specific technological relatedness to foreign affiliates active in the provincial market on local 
firms' probability to act as pioneers for some specific productions and we compare the effectiveness of these knowledge transfers to that of extra-regional knowledge embedded in imported products. Third, we investigate whether the notion of technological relatedness behind our main hypotheses and results can be reconciled with the mechanisms thoroughly explored by the international business literature stemming from vertical linkages with MNEs (Cantwell and Iguchi, 2005; Jindra et al., 2009; Giroud et al., 2012). We contribute to this stream of research by dissecting, within a systematic empirical analysis covering the quasi totality of a country's manufacturing production, a detailed product-specific dimension of knowledge spillovers which extends the potential knowledge transmission channels beyond vertical linkages to a wider possibility of interactions and exchanges among diverse local actors.

The emerging Turkish economy is a particularly suitable context for our aims. Turkey's manufacturing production structure underwent important changes over the last decades (Hidalgo, 2009). Furthermore, the Turkish economy has dramatically increased its international involvement in global production networks (GPNs): during the period under analysis, the country has recorded an unprecedented upsurge both in FDI and imports which could have driven relevant knowledge spillovers into the local economies. In particular, the wider pool of capabilities owned by MNEs with respect to Turkish domestic firms (Javorcik et al., 2017) represents an important element that could drive to a radical change of the existing local production structure. Finally, relevant territorial disparities characterise the country. A laggard East, indeed, contrasts with a more developed West, in terms of production structure, international integration and presence of MNEs' affiliates.

The work is structured as follows. In Section 2, we review the relevant literature and introduce our working hypotheses. In Section 3, we describe the data, the measures of technological relatedness and present our empirical model. Section 4 presents the results of the empirical test of our hypotheses, discusses the robustness checks and explores some possible mechanisms behind our main findings. Section 5 concludes.

\section{Technological relatedness, intra- and extra-regional knowledge and local discoveries}

Geographical proximity favours the sharing of social, cultural and institutional contexts which eases reciprocal understanding and the flow of tacit knowledge among diverse agents (Shefer and Frenkel, 1998; Gertler, 2003; Howells, 2012; Rodríguez-Pose and Comptour, 2012; Poon et al., 2013). However, for knowledge to spill among local actors a certain extent of cognitive proximity is required so that firms' capabilities can complement each other (Nooteboom, 2000; Boschma, 2005). In this line, recent empirical work in economic geography has explored the importance of technologically related knowledge as a significant determinant of regional growth and diversification into new industries (Porter, 2003; Neffke et al., 2011; Boschma et al., 2013; Castaldi et al., 2015; Miguelez and Moreno, 2017). In particular, for the country of our analysis, Lo Turco and Maggioni (2016) have compared the relative contribution of the firm and local level product-specific competencies in fostering product innovation. Their findings show that path dependence is importantly relaxed by a firm's involvement in foreign markets. This calls for a potential path-breaking role of extra-regional knowledge in 
shaping the evolution of local product space. As a matter of fact, external knowledge accruing to a region through local actors involved in GPNs, ${ }^{1}$ as well as through imports, may enlarge local firms' view on the set of new potential production opportunities to reap and may help preventing suboptimal and excessive cluster specialisation (Shane, 2000; Lambooy and Boschma, 2001; Asheim and Isaksen, 2002). Linkages with external actors may spur the collection of capabilities which, although technologically related, are different and relatively more distant than the local pool of skills and competencies and can fruitfully complement them to create new development trajectories (Bathelt et al., 2004). This leads to the basic premise of our work on the significant role of technologically related extra-regional knowledge in fostering local firms' introduction of local discoveries. The empirical literature offers several examples in this direction. For Germany, Hausmann and Neffke (2016) show that, in order to retrieve the relevant capabilities, it is vital for pioneer firms to source related skills externally, while Neffke et al. (2014) show that, in Sweden, structural change mostly originates via new establishments coming from outside the region. In a similar vein, Boschma and Iammarino (2009) find an important effect of related extra-regional knowledge - namely knowledge embedded in imported related varieties - in shaping the process of regional growth in Italy.

International knowledge search and discovery of new combinations importantly rely on the role of MNEs in establishing and favouring greater connectivity between spatially dispersed knowledge sources (Cantwell, 2017). In the international business literature, extensive work on East Asian countries has shown that MNEs active in GPNs have transferred tacit knowledge to local suppliers usually involved in low valueadded assembly activities (Ernst and Kim, 2002; Giroud and Mirza, 2006; Giroud, 2007). In emerging markets, then, MNEs' affiliates represent unprecedented global knowledge connectivity opportunities which are at the basis of the process of new knowledge creation that allows to gradually move up the value chain to higher value activities (Kogut, 2000; Coviello, 2006; Mudambi, 2008; Johanson and Vahlne, 2009). They could, then, act as technological gatekeepers who, characterised by large knowledge endowments and strong external linkages, share their knowledge with other firms in the cluster and therefore drive and dominate localised knowledge spillovers (Morrison, 2008; Giuliani, 2011; Graf, 2011; Munari et al., 2012). Wang and Wu (2016) corroborate this view. For the Chinese electronics industry in 2009, they find, indeed, that localised innovative activities of foreign firms exert positive and significant influences on the output share of new products added by co-located domestic firms.

Turning to the import channel, goods sourced abroad can incorporate relevant technological advances and, then, represent a complementary source of extra-regional knowledge. Imports can favour the introduction of new products by making previously inaccessible input varieties available to local firms. In this direction are the theory and evidence provided by Colantone and Crinò (2014) who, on a sample of European countries, show that importing new inputs helps introducing new products. However, while most of the knowledge transferred by local MNEs is expected to be tacit and effectively transferred through personal interactions and exchanges (Ernst and Kim,

1 The literature has, indeed, highlighted the importance of considering GPNs in the study of the subnational economic development as they represent platforms allowing the involved actors to reshape knowledge, compete and cooperate (Coe and Yeung, 2015), with relevant repercussions on the production of economic value. 
2002; Lorenzen and Mudambi, 2013), tacit knowledge embedded in imports could remain an unexploited potential as the lack of human interactions can hamper its release. Results by Zhu et al. (2017) support this possibility. For Chinese districts, they test how an industry's path dependence-measured as technological proximity with respect to the local export mix - is relaxed by FDI and imports accruing to the same industry in the same location. They find that, while an increase in FDI reduces the effect of path dependence, knowledge embedded in sectoral imports does not moderate the role of local density in determining the evolution of local comparative advantages.

Considered all the above theoretical discussion and empirical findings, in this paper we aim at testing the following hypotheses:

HP1a: Related knowledge spilling from co-located foreign MNEs fosters the introduction of product discoveries by local firms.

HP1b: Related knowledge spilling from co-located foreign MNEs fosters the introduction of product discoveries more effectively than related knowledge spilling from imports and from colocated domestic firms.

With respect to the above mentioned literature, rather than inspecting how new export comparative advantages emerge in a location, the use of detailed data on firms' production structure allows us to depict how brand new productions start. Also, we move a step further by directly testing the extent of detailed product-specific knowledge transfers spilling from the overall product mix of foreign firms - as well as of domestic firms, and imports - active in a specific province and, hence, by dissecting the mechanisms through which co-located foreign firms may relax path-dependence.

In this respect, we further shed light on the conditions under which knowledge transfers from foreign affiliates are effective. Although we would expect that MNEs act as technological gatekeepers sharing their knowledge with local firms, thus enabling them to reap new production opportunities, under some circumstances this transfer of knowledge from MNEs to local firms could not occur. ${ }^{2}$ First, despite the existence of geographic and cognitive relatedness, local domestic firms could lack the needed absorptive capacity to convert knowledge into internalised capabilities (Cohen and Levinthal, 1990; Kim, 1998; Zahra and George, 2002). In this respect, Miguélez and Moreno (2015) show that regional absorptive capacity is a key element that allows European regions to transform the external knowledge, conveyed in their study by inventor mobility and networks, into innovation. Second, MNEs' subunits might be prevented to share their knowledge with local firms for two kinds of reasons. On the one hand, the liability of foreignness, stemming from the difficulty of building relationships in the host economy and from the lack of institutional market knowledge (Zaheer, 1995; Johanson and Vahlne, 2009), can further exacerbate the initial outsider status of foreign firms in the local firm network. MNEs' affiliates are insiders in the MNEs' global network, but are outsiders when first entering a foreign local market, due to their lack of market-specific business knowledge. Then, it may take some time for the foreign firm to take a position in the local network (Kiyota et al., 2008; Giroud and

2 As an example, they could locate in clusters to acquire, rather than release, local knowledge (Anand and Delios, 2002; Wang and Guo, 2017; Fuller and Phelps, 2018). However, given the empirical setting under our investigation, it is likely that the role of foreign firms as knowledge providers and as bridge between external and local knowledge is prominent. 
Scott-Kennel, 2009) and to activate the process of learning and trust and commitment building. On the other hand, a MNE's strategy could be directed to protect the firmspecific advantage, thus preventing the transfer of knowledge and technology to the remaining local firms. In this respect, we put ahead a further hypothesis:

HP2: Related knowledge transfers from local foreign MNEs' affiliates are more effective: a) the higher is local firms' absorptive capacity; b) the higher is MNEs' affiliates' insidership in the local market; c) the weaker is their product-specific knowledge ownership advantage in the global market.

\section{Empirical strategy}

\subsection{Firm level data sources, sample and definitions}

Our data set originates from the merging of the Turkish Structural Business Statistics (SBS), Annual Industrial Product Statistics (AIPS) and Foreign Trade Statistics (FTS), all available from the Turkish Statistical Office (TurkStat). SBS provide a firm's number of employees, labour productivity, wage and, importantly for our aims, information on the NUTS3 location of the firm's plants and on foreign ownership. We define foreign firms as firms with a foreign capital share equal to or higher than $10 \%$ (International Monetary Fund, 1993; OECD, 2008), all other firms are instead considered as domestic. In our sample period, foreign owned firms are 3494, corresponding to $4 \%$ of all firms active in the Turkish manufacturing production, they are responsible of about $21 \%$ of Turkish manufacturing output and their product mix is made up of more sophisticated goods, that is goods requiring more exclusive and complex capabilities (Hausmann and Hidalgo, 2009; Javorcik et al., 2017).

AIPS inform on all 10-digit 2006 PRODTR goods produced by all Turkish firms with more than 20 persons employed active in manufacturing over the period 2005-2009. PRODTR is a Turkish classification whose first six-digit correspond the 2002 CPA classification adopted by the European Union.

To measure extra- and intra-regional-related knowledge, we retrieve the NUTS3 level set of imported goods from FTS - that also allow us to identify firms' importer and exporter status - and the domestic and foreign production structure from the merging of AIPS and SBS. ${ }^{3}$ The technological relatedness measure between products that we use in our empirical model is obtained by exploiting six-digit 1996 Harmonised System (1996HS) world trade flows. As a consequence, the sets of import goods and the product mix of foreign and domestic firms active in each NUT3 province are all defined at the HCPA product level classification which is obtained by harmonising the 1996-HS and 2002 CPA classifications. HCPA is just slightly more aggregated than the CPA classification, and contains 1297 products of which 1030 are actually produced in Turkey.

Although the higher detail of the PRODTR classification could not be used for measuring relatedness, we can still hinge on it for the definition of local discoveries. As

3 For multi-province firms, we assumed that each plant's production was proportional to its share in a firm's turnover. Concerning the relevance of our sample, in the period of our analysis, according to official Turkstat data, the manufacturing production value generated by firms with more than 20 employees accounted for about $89 \%$ of the total. Also, firms in our sample have a median size of around 40 employees. More details on the size distribution of firms in our work are not reported for the sake of brevity, nevertheless they are readily available in the Online Appendix. 
a matter of fact, by observing firms' product scope over time, we are able to identify newly introduced products as new PRODTR codes appearing in their product basket. In the following, we refer to a 10-digit PRODTR code as product and to a six-digit HCPA code as product category. We label local discoveries firms' new PRODTR products within a HCPA product category which were never produced in the NUTS3 firm's location province(s). We, therefore, define discoveries firm's products that are new both to the firm and its local market to distinguish them from new products that are just new to the firm. Hence, 'local' refers to the geographical scope of novelty of the product which, then, could be already produced somewhere else in Turkey and in the world. The local market corresponds to the specific firm's NUTS3 location province(s) - available from SBS - among the 81 NUTS3 Turkish provinces.

Finally, as our interest relies on the analysis of how local firms' probability to add a specific product discovery is affected by the extent of technological relatedness to different sources of local knowledge, our estimation sample is made up of Turkish manufacturing firms with more than 20 persons employed introducing a new product in the period 2006-2009. In the sample, we have 7051 firms which introduce a new product in the mentioned time span. Of these, 1691 firms introduce at least one of the 2259 local product discoveries in Turkish NUTS3 provinces and therefore, henceforth, we refer to these firms as local pioneers. ${ }^{4}$

In Table 1 we show the distribution of local discoveries by sector. The Machinery industry by itself accounts for more than one-fifth of the total number of local discoveries. More than half of discoveries in this industry concerns pumps and compressors, agricultural machinery and general and special purpose machineries. However, local discoveries can be found both in comparative advantage/traditionale.g. Textile and Clothing - and disadvantage/advanced - Chemicals and Machineriessectors, but in all cases they are expected to represent a substantial advancement with respect to the current domestic technological frontier. To examine this issue, we hinge on the product complexity indicator proposed by Hausmann and Hidalgo (2009) which reflects the capabilities content of products. If high complexity goods require exclusive and diverse capabilities for their production, they will be less ubiquitously produced around the world and their production will be concentrated in a few countries mainly producing other sophisticated products. Hausmann and Hidalgo (2009) develop a measure of product ubiquity from the world trade network connecting countries to the products they export and, through an iterative method, they refine the notion of ubiquity on the basis of countries' export diversification. ${ }^{5}$ Across the HCPA product classification at our disposal, the standardised version of the Hausmann and Hidalgo's (2009) complexity indicator ranges from -2.6 up to 2.6. By considering all products newly introduced by Turkish firms, while local discoveries have an average complexity level of 0.084 , products that are new just to the firm but not to the local market have an average complexity level of -0.590 . A simple $t$-test for the difference in the mean complexity level between product discoveries and the rest of new products confirms,

4 Hausmann and Neffke (2016) label as pioneers those firms that first enter an under-represented NACE rev 1.1 4-digit industry in a location. Our definition is more demanding, as we require that the product was never locally produced before, although the location could have already produced other products in the same six-digit HCPA product category.

5 More details on the distribution of discoveries by sector and on the definition of product complexity à la Hausmann and Hidalgo (2009) are available in the Online Appendix. 
Table 1. Local discoveries by sector

\begin{tabular}{lcc}
\hline NACE rev.1.1 & Freq. & Relative Freq. (\%) \\
\hline & & 22 \\
29 Machineries & 508 & 12 \\
15 Food & 267 & 7 \\
24 Chemicals & 164 & 7 \\
28 Steel products & 153 & 6 \\
17 Textiles & 141 & 6 \\
18 Apparel & 134 & 5 \\
26 Non-metallic mineral products & 117 & 5 \\
25 Rubber and plastics & 112 & 4 \\
27 Basic metals & 98 & 4 \\
36 Furniture & 91 & 4 \\
31 Electrical machinery & 87 & 3 \\
20 Wood products & 75 & 3 \\
21 Paper products & 58 & 11 \\
Other sectors & 254 & \\
& 2259 & \\
\hline
\end{tabular}

indeed, that the former are significantly and considerably more complex than the latter ( $T$-statistics equal to 29.37). Not only local discoveries are more sophisticated than the remaining new products, but also local pioneers are more sophisticated than other innovators - firms that introduce new products which cannot be defined as local discoveries - as $T$-tests for the difference in means reveal that they have a significantly higher share of employment devoted to $R \& D$ and a more complex product mix. ${ }^{6}$

\subsection{Measuring technological relatedness}

We measure technological relatedness by means of the product proximity indicator suggested by Hidalgo et al. (2007). The underlying idea of this indicator is that, if products $j$ and $p$ require a similar pool of skills and knowledge, they will likely co-occur in countries' export/production baskets. To measure technological relatedness between any two products $j$ and $p$, we then calculate the conditional probability of one good being exported, given that the other is exported on the basis of the matrix of countryproduct exports for year 2002 available from the CEPII BACI database (Gaulier and Zignago, 2010). Namely, to purge the final indicator from scale effects, we actually identify the set of revealed comparative advantage (RCA) products for each country $c$ by means of a dummy $d \mathrm{RCA}_{c p}$ which is equal to 1 if country $c$ has a $\mathrm{RCA}_{c p}$ index higher than 1 in product $p$ and zero otherwise (Balassa, 1965). ${ }^{7}$ Then, we obtain technological proximity between products $p$ and $j$ as the minimum between the probability that good

Detailed results on $T$-tests are available upon request.

$$
\mathrm{RCA}_{c p}=\frac{\frac{\text { country } c^{\prime} \text { s exports of product } p}{\text { total country } c^{\prime} \text { sexports }}}{\frac{\text { world exports of product } p}{\text { world total exports }}} \text { with } 0 \leq \mathrm{RCA}_{c p}<\infty .
$$

Hence, country $c$ exports product $p$ with comparative advantage if the RCA index for the product is higher than 1. 
$p$ is exported conditional on good $j$ being exported and the probability that good $j$ is exported conditional on good $p$ being exported:

$$
\phi_{p j}=\min \left\{P\left(d \mathrm{RCA}_{c p} \mid d \mathrm{RCA}_{c j}\right), P\left(d \mathrm{RCA}_{c j} \mid d \mathrm{RCA}_{c p}\right)\right\},
$$

$\phi_{p j}$, thus, gives a measure of the overlap between the pool of production capabilities required by the goods $p$ and $j$.

In order to investigate and dissect the effect of the different local sources of knowledge on a firm's likelihood to introduce a local discovery, by exploiting the technological relatedness measure for each products pair just described above, we compute the following weighted average proximity indicators at province $l$ and product $p$ level:

$$
\begin{gathered}
\phi_{l p}^{\text {for }}=\sum_{j \in S_{l}^{\text {for }}, j \neq p} \phi_{p j} * \frac{\operatorname{production}_{l j}^{\text {for }}}{\sum_{j \in S_{l}^{\text {for }}} \operatorname{production}_{l j}^{\text {for }}}, \\
\phi_{l p}^{\text {imp }}=\sum_{j \in S_{l}^{\text {simp }}, j \neq p} \phi_{p j} * \frac{\text { imports }_{l j}}{\sum_{j \in S_{l}^{\text {imp }}} \operatorname{imports}_{l j}}, \\
\phi_{l p}^{\text {dom }}=\sum_{j \in S_{l}^{\mathrm{dom}}, j \neq p} \phi_{p j} * \frac{\operatorname{production}_{l j}^{\text {dom }}}{\sum_{j \in S_{l}^{\text {dom }}} \operatorname{production}_{l j}^{\text {dom }}},
\end{gathered}
$$

where $S_{l}^{\text {for }}, S_{l}^{\text {dom }}$ and $S_{l}^{\text {imp }}$ are the sets of goods that are produced by local foreign and domestic firms and imported by all firms active in province $l .{ }^{8}$ Thus, $\phi_{l p}^{\text {for }}, \phi_{l p}^{\text {imp }}$ and $\phi_{l p}^{\text {dom }}$ measure the technological proximity between product $p$ and the pool of productive capabilities embedded in the local production attributable to foreign firms, imports and domestic firms, respectively. For those firms active in more than one province, we average these proximity indicators across all provinces where they have a plant, by weighing each provincial indicator by the firms' output share produced in that province.

Finally, we also measure the technological proximity of a product $p$ to a firm's existing pool of productive capabilities which is reflected in its existing product scope $\left(S_{i}\right)$ (Breschi et al., 2003; Neffke and Henning, 2013; Lo Turco and Maggioni, 2016):

$$
\phi_{i p}^{\mathrm{firm}}=\sum_{j \in S_{i}, j \neq p} \phi_{p j} * \frac{\operatorname{production}_{i j}}{\sum_{j \in S_{i}} \text { production }_{i j}} .
$$

8 To purge the proximity measures from scale effects in Equations (1) and (3), the sets $S_{l}^{\text {for }}$ and $S_{l}^{\text {dom }}$ only include foreign and domestic firms' specialisation products, that is, goods whose share in total foreign/ domestic production in province $l$ is higher than the total share of the same product in the Turkish aggregate manufacturing production. Similarly, in Equation (2), the $S_{l}^{\text {imp }}$ set is made up of products whose share in total provincial imports is higher than their share in world imports. 


\subsection{Empirical model}

In order to explore whether and how, in the Turkish context, local discoveries depend on the extent of their technological proximity to sources of extra- and intra-regional knowledge, we estimate the following linear probability model (LPM):

$$
\begin{aligned}
I_{i p t}^{\mathrm{NUTS} 3}= & \alpha+\beta_{1} \phi_{l p t-1}^{\mathrm{for}}+\beta_{2} \phi_{l p t-1}^{\mathrm{imp}}+\beta_{3} \phi_{l p t-1}^{\mathrm{dom}}+\beta_{4} \phi_{i p t-1}^{\mathrm{firm}} \\
& +\gamma^{\prime} X_{i t-1}+\eta_{i}+\chi_{p}+\lambda_{t}+\epsilon_{i p t}
\end{aligned}
$$

where $I_{i p t}^{\mathrm{NUTS} 3}$ is a dummy denoting the introduction of a local discovery. Then, it is equal to 1 if at time $t$ firm $i$ starts producing at least one new 10-digit productwithin the six-digit category $p$-which was not produced in any of the previous sample years and in any of the NUTS3 regions where firm $i$ is active. On the contrary, the dummy takes the value of 0 for any six-digit product category $p$, belonging to any of the two-digit NACE sectors where the firm was active in $t-1$ (Frenken et al., 2007; Neffke and Henning, 2013), which has never been produced by any firm - including $i$ - in any of the firm's NUTS3 location regions either at time $t$ or before.

Local discoveries are a rare event. The dummy $I_{i p t}^{\text {NUTS3 }}$ takes value 1 for $0.69 \%$ of our sample of 328,876 firm-product-year observations referred to potential discoveries.

The main variables of interest in model (5) are $\phi_{l p t-1}^{\text {for }}, \phi_{l p t-1}^{\mathrm{imp}}$ and $\phi_{l p t-1}^{\mathrm{dom}}$, which, respectively, measure the cognitive proximity between product $p$ and the pool of productive capabilities embedded in the local production attributable to foreign firms, imports and domestic firms at time $t-1$. Finally, $\phi_{i p t-1}^{\text {firm }}$ reflects the technological proximity between the new potential products $p$ and a firm's own internal capabilities in the previous year reflected in their product mix.

Our empirical model includes a number of time-varying firm level controls $X_{i t-1}$ which are firm size (lab), labour productivity (lab_prod), export (exp), import (imp), and foreign ownership status (foreign) and a dummy for multi-plant firms (multiplant). All regressors appear at time $t-1$ in order to mitigate simultaneity concerns and the model also includes firm-fixed effects $\eta_{i}$, product-fixed effects $\chi_{p}$ and year dummies $\lambda_{t}$. Finally, standard errors are clustered at the firm level. In the Online Appendix, Table O-5 lists and describes the variables used in the empirical analysis, while Online Appendix Tables O-6 and O-7, respectively, show descriptive statistics of the variables of interest and correlations among them.

\section{Results}

\subsection{Related extra- and intra-regional knowledge and local discoveries}

Table 2 reports the results of the estimation of Equation (5). Related knowledge spilling from foreign firms is positively and significantly associated to local firms' probability of starting producing a specific new good never produced before in any of their NUTS3 location region(s). This result is robust to the inclusion of the remaining proximity variables. Our hypothesis HP1a is thus corroborated. The coefficient in Column [5] implies that one standard deviation increase of a product's proximity to foreign firms' production bundle enhances a firm's probability to introduce that product by 0.13 
Table 2. Related extra- and intra-regional knowledge and local discoveries

\begin{tabular}{|c|c|c|c|c|c|}
\hline & \multicolumn{5}{|c|}{ Product discoveries in the NUTS 3 region $-I_{i p t}^{\text {NUTS3 }}$} \\
\hline & [1] & {$[2]$} & {$[3]$} & {$[4]$} & {$[5]$} \\
\hline$\phi_{l p}^{\text {for }}$ & $\begin{array}{l}0.020 * * * \\
{[0.005]}\end{array}$ & & & & $\begin{array}{l}0.017^{* * *} * \\
{[0.005]}\end{array}$ \\
\hline$\phi_{l p}^{\mathrm{dom}}$ & & $\begin{array}{c}0.017 * \\
{[0.009]}\end{array}$ & & & $\begin{array}{c}-0.002 \\
{[0.010]}\end{array}$ \\
\hline$\phi_{l p}^{\mathrm{imp}}$ & & & $\begin{array}{c}0.015^{*} \\
{[0.008]}\end{array}$ & & $\begin{array}{c}0.004 \\
{[0.008]}\end{array}$ \\
\hline$\phi_{i p}^{\text {firm }}$ & & & & $\begin{array}{l}0.054 * * * \\
{[0.004]}\end{array}$ & $\begin{array}{l}0.054 * * * \\
{[0.004]}\end{array}$ \\
\hline lab & $\begin{array}{c}0.001 \\
{[0.001]}\end{array}$ & $\begin{array}{c}0.001 \\
{[0.001]}\end{array}$ & $\begin{array}{c}0.001 \\
{[0.001]}\end{array}$ & $\begin{array}{c}0.002 \\
{[0.001]}\end{array}$ & $\begin{array}{c}0.001 \\
{[0.001]}\end{array}$ \\
\hline lab_prod & $\begin{array}{c}0.000 \\
{[0.001]}\end{array}$ & $\begin{array}{c}0.000 \\
{[0.001]}\end{array}$ & $\begin{array}{c}0.000 \\
{[0.001]}\end{array}$ & $\begin{array}{c}0.000 \\
{[0.001]}\end{array}$ & $\begin{array}{c}0.000 \\
{[0.001]}\end{array}$ \\
\hline $\exp$ & $\begin{array}{c}0.000 \\
{[0.001]}\end{array}$ & $\begin{array}{c}0.000 \\
{[0.001]}\end{array}$ & $\begin{array}{c}0.000 \\
{[0.001]}\end{array}$ & $\begin{array}{c}0.000 \\
{[0.001]}\end{array}$ & $\begin{array}{c}0.000 \\
{[0.001]}\end{array}$ \\
\hline imp & $\begin{array}{c}0.001 \\
{[0.001]}\end{array}$ & $\begin{array}{c}0.001 \\
{[0.001]}\end{array}$ & $\begin{array}{c}0.001 \\
{[0.001]}\end{array}$ & $\begin{array}{c}0.001 \\
{[0.001]}\end{array}$ & $\begin{array}{c}0.001 \\
{[0.001]}\end{array}$ \\
\hline foreign & $\begin{array}{c}0.004 \\
{[0.003]}\end{array}$ & $\begin{array}{c}0.005 \\
{[0.003]}\end{array}$ & $\begin{array}{c}0.005 \\
{[0.003]}\end{array}$ & $\begin{array}{c}0.005^{*} \\
{[0.003]}\end{array}$ & $\begin{array}{c}0.005 \\
{[0.003]}\end{array}$ \\
\hline multiplant & $\begin{array}{c}0.001 \\
{[0.001]}\end{array}$ & $\begin{array}{l}0 \\
{[0.001]}\end{array}$ & $\begin{array}{c}0.001 \\
{[0.001]}\end{array}$ & $\begin{array}{c}0.001 \\
{[0.001]}\end{array}$ & $\begin{array}{c}0.001 \\
{[0.001]}\end{array}$ \\
\hline Fixed effects & & & & & \\
\hline Firm & Yes & Yes & Yes & Yes & Yes \\
\hline Product & Yes & Yes & Yes & Yes & Yes \\
\hline Year & Yes & Yes & Yes & Yes & Yes \\
\hline Observations & 328,867 & 328,867 & 328,867 & 328,867 & 328,867 \\
\hline$R^{2}$ & 0.148 & 0.148 & 0.148 & 0.149 & 0.15 \\
\hline
\end{tabular}

Notes: Robust standard errors clustered at the firm level are shown in brackets. The dependent variable is $I_{i p t}^{\text {NUTS3 }}$, a dummy variable denoting a firm $i$ 's probability to introduce local discovery $(p)$. $*, * *, * *$ Significant at $10 \%, 5 \%$ and $1 \%$ levels.

percentage points. ${ }^{9}$ This effect is sizable when compared with the average firm probability of adding a product in our sample-from Online Appendix Table O-6 $0.7 \%$ - and, then, the effect of technological relatedness to foreign firms is not only statistically significant but also economically meaningful. Furthermore, the table also confirms hypothesis HP1b, as it documents the superiority of knowledge fueling from co-located foreign affiliates with respect to other sources of extra- and intra-regionalrelated knowledge. More specifically, results point at the lack of any effect played by technological-related knowledge embedded in local import flows. The different relevance of foreign firms and imports as sources of related knowledge hints at the importance of the tacit component of knowledge which underscores the need of personal interactions

9 As a matter of fact, from Online Appendix Table O-6, the standard deviation of $\phi_{l p}^{\text {for }}$ in our sample is equal to 0.074 . Then, being $\hat{\beta}_{1}=0.017$, the total effect of one standard deviation increase of our variable of interest is $0.017 * 0.074=0.001258$ which implies an increase of about 0.13 percentage points in the probability to introduce product $p$. 
to be transmitted. Furthermore, the table shows the lack of any role for knowledge spilling from co-located domestic firms. A large distance between the existing pool of capabilities and the requirements of the discoveries, on the one side, and its environment, on the other, could explain this finding (Boschma and Frenken, 2006). Finally, our results on $\phi^{\text {firm }}$ confirm previous evidence on the significant role played by firms' own internal resources (Danneels, 2002; Breschi et al., 2003; Neffke and Henning, 2013; Lo Turco and Maggioni, 2016).

The baseline evidence from Column [5] is robust to alternative sampling and variables definition and to the control for omitted variables. ${ }^{10}$ In terms of sample composition, results are confirmed when we exclude foreign firms - accounting for 3\% of firms in our sample - from the estimation, when we drop the first sample year-2006 - for which new products are referred to one previous year only, and when in the definition of the dependent variable, $I_{i p t}^{\mathrm{NUTS} 3}$, we consider as 0 s all new potential products never produced in the local market, beyond those in the firm's two-digit industry. Furthermore, to account for the sample selection, we extend our analysis to non-innovators by controlling for the firms' past innovation activity and results stay unchanged. We also prove the robustness of our findings to the control of further covariates, such as the share of foreign and imported production in the province, the number of goods produced by co-located foreign/domestic firms and the number of imported goods. We, then, test for different measures of technological relatedness by computing the proximity measures on all products included in the set of provincial foreign/domestic production and imports and by considering just the main firm's province in the proximity calculations. We alternatively cluster standard errors by product or by province rather than by firm. Finally, our evidence is not affected by the potential effect of spatial dependence that we account for by spatially lagging the dependent variable and the proximity indicators.

Capabilities transferred by co-located foreign firms are, then, relevant for introducing local discoveries. As previously discussed, discoveries turn to be more complex-in terms of capabilities content - than other products newly introduced by firms. It follows that foreign MNEs' affiliates possibly transfer new and sophisticated capabilities to local firms which can, thereby, envisage and reap brand new production opportunities. Hence, knowledge transfers from MNEs should matter less for the introduction of the remaining new products because they are relatively more simple products. To inspect whether the product complexity is the driver of our baseline results on local discoveries, we consider a broader definition of innovation. Namely, we replace the dependent variable of model (5) with a dummy variable for products new to the firm and not necessarily new to its local market, $I_{i p t}$. The dummy then takes value 1 if firm $i$ at time $t$ introduces a new 10-digit product within a six-digit product category $p$ which it was not producing at time $t-1$. Findings in Columns [1]-[5] of Table 3 firstly reveal that technological proximity to foreign firms does not play any role for the introduction of products that are new to the firm but not necessarily new to the province, while technological proximity to co-located domestic firms turns now to matter. The role of knowledge sources then differs across different types of innovation. In Columns [6][10], we further extend the model by including the interactions between all the four

10 Detailed results on the robustness checks are not shown for the sake of brevity and are available in the Online Appendix. 


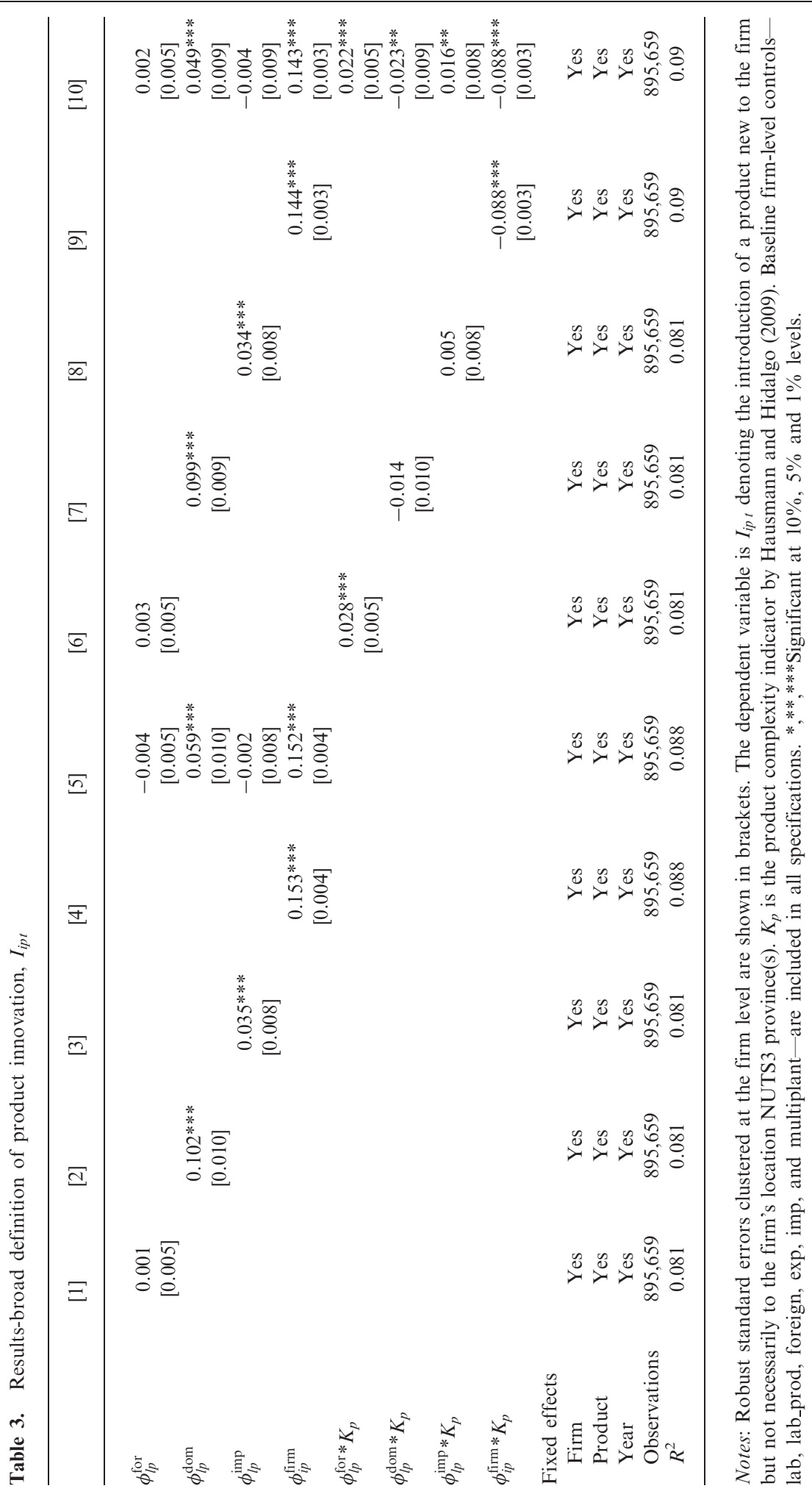


Table 4. Product innovation, $I_{i p t}$, and related knowledge: does product complexity matter?

\begin{tabular}{|c|c|c|c|c|}
\hline $\begin{array}{l}\mathrm{K}_{\mathrm{p}} \\
\text { Percentile }\end{array}$ & \multicolumn{3}{|c|}{ Products new to the firm- $I_{i p t}$} & $\phi_{i p}^{\mathrm{firm}}$ \\
\hline 10th & $\begin{array}{c}-0.031 * * * \\
{[0.009]}\end{array}$ & $\begin{array}{l}0.084 * * * \\
{[0.018]}\end{array}$ & $\begin{array}{c}-0.028^{*} \\
{[0.017]}\end{array}$ & $\begin{array}{l}0.275^{* * *} \\
{[0.007]}\end{array}$ \\
\hline 25 th & $\begin{array}{c}-0.015^{* *} \\
{[0.007]}\end{array}$ & $\begin{array}{l}0.067 * * * \\
{[0.012]}\end{array}$ & $\begin{array}{c}-0.017 \\
{[0.012]}\end{array}$ & $\begin{array}{l}0.212 * * * \\
{[0.005]}\end{array}$ \\
\hline Median & $\begin{array}{c}0.002 \\
{[0.005]}\end{array}$ & $\begin{array}{l}0.049 * * * \\
{[0.009]}\end{array}$ & $\begin{array}{c}-0.004 \\
{[0.009]}\end{array}$ & $\begin{array}{l}0.141^{* * *} \\
{[0.003]}\end{array}$ \\
\hline 75 th & $\begin{array}{l}0.018^{* * * *} \\
{[0.005]}\end{array}$ & $\begin{array}{l}0.032 * * * \\
{[0.011]}\end{array}$ & $\begin{array}{c}0.008 \\
{[0.009]}\end{array}$ & $\begin{array}{l}0.077^{* * * *} \\
{[0.003]}\end{array}$ \\
\hline 90th & $\begin{array}{l}0.028 * * * \\
{[0.007]}\end{array}$ & $\begin{array}{c}0.02 \\
{[0.014]}\end{array}$ & $\begin{array}{c}0.015 \\
{[0.011]}\end{array}$ & $\begin{array}{l}0.034^{* * * *} \\
{[0.004]}\end{array}$ \\
\hline
\end{tabular}

Notes: $I_{i p t}$ is a dummy taking value 1 if firm $i$ at time $t$ introduces a new 10-digit product within a six-digit product category $p$ which it was not producing at time $t-1 . K_{p}$ is the product complexity indicator by Hausmann and Hidalgo (2009). The table reports the impact of the relatedness measures by percentile of the distribution of complexity of the potential new products, $K_{p}$, on the basis of the estimations reported in Table 3. $* * * * * *$ Significant at $10 \%, 5 \%$ and $1 \%$ levels.

technological proximity measures we explore and the product $p$ 's complexity, $K_{p}$, measured à la Hausmann and Hidalgo (2009). It emerges that relatedness to foreign firms is significantly and positively moderated by product complexity which also shapes, although in an inverse manner, the impact of relatedness to co-located domestic firms. In Table 4, the estimates of the marginal effects by some selected percentiles of the product complexity distribution corroborate the view that local discoveries, which are relatively more complex than the remaining new products in the province, call for capabilities which are locally unavailable and can just be provided by external knowledge brought by foreign affiliates.

\subsection{The effectiveness of foreign knowledge transfers: local firms' and MNEs' heterogeneity}

We have shown that knowledge spilling from foreign firms is a relevant determinant for the introduction of local discoveries. We now aim at presenting the empirical test of hypothesis HP2 by dissecting the conditions that can favour or limit foreign firms' knowledge transfers. As discussed in our theoretical and empirical literature background, we investigate the role of local firms' absorptive capacity (Miguélez and Moreno, 2015), of MNEs' extent of insidership in the local market and of their strategic position in the product-specific knowledge creation in the world markets (Johanson and Vahlne, 2009).

Results are presented in Table 5. In the first part of the table, we test the relevance of local firms' absorptive capacity by splitting the sample between firms with labour productivity above or below the sample median (Haskel et al., 2007). From the coefficient estimates (Columns [1]-[2]) and the corresponding tests at the bottom of the table, it emerges that the role of foreign firms is more relevant for high productivity firms, that is for firms that have a higher chance to grasp the knowledge transferred by 


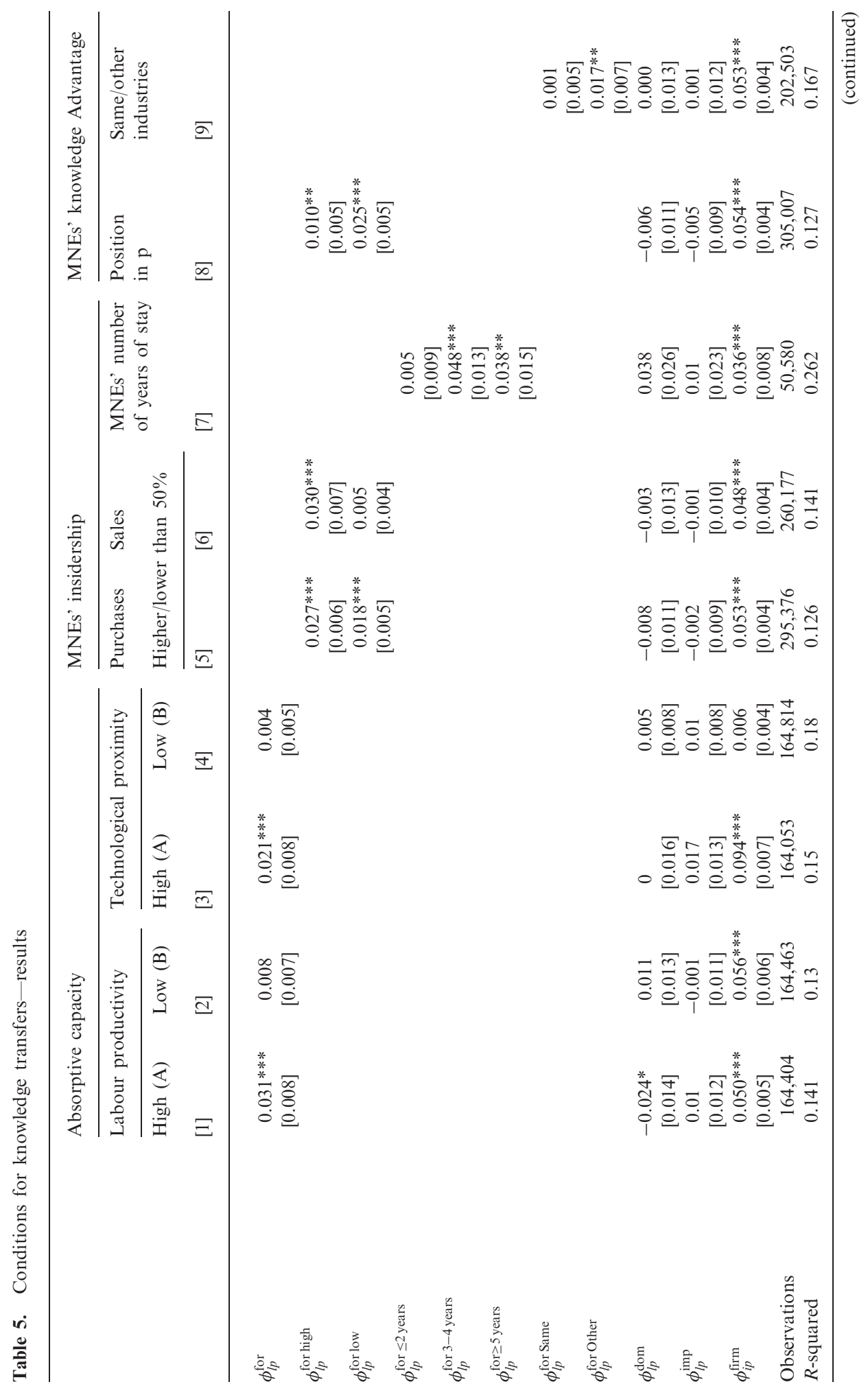




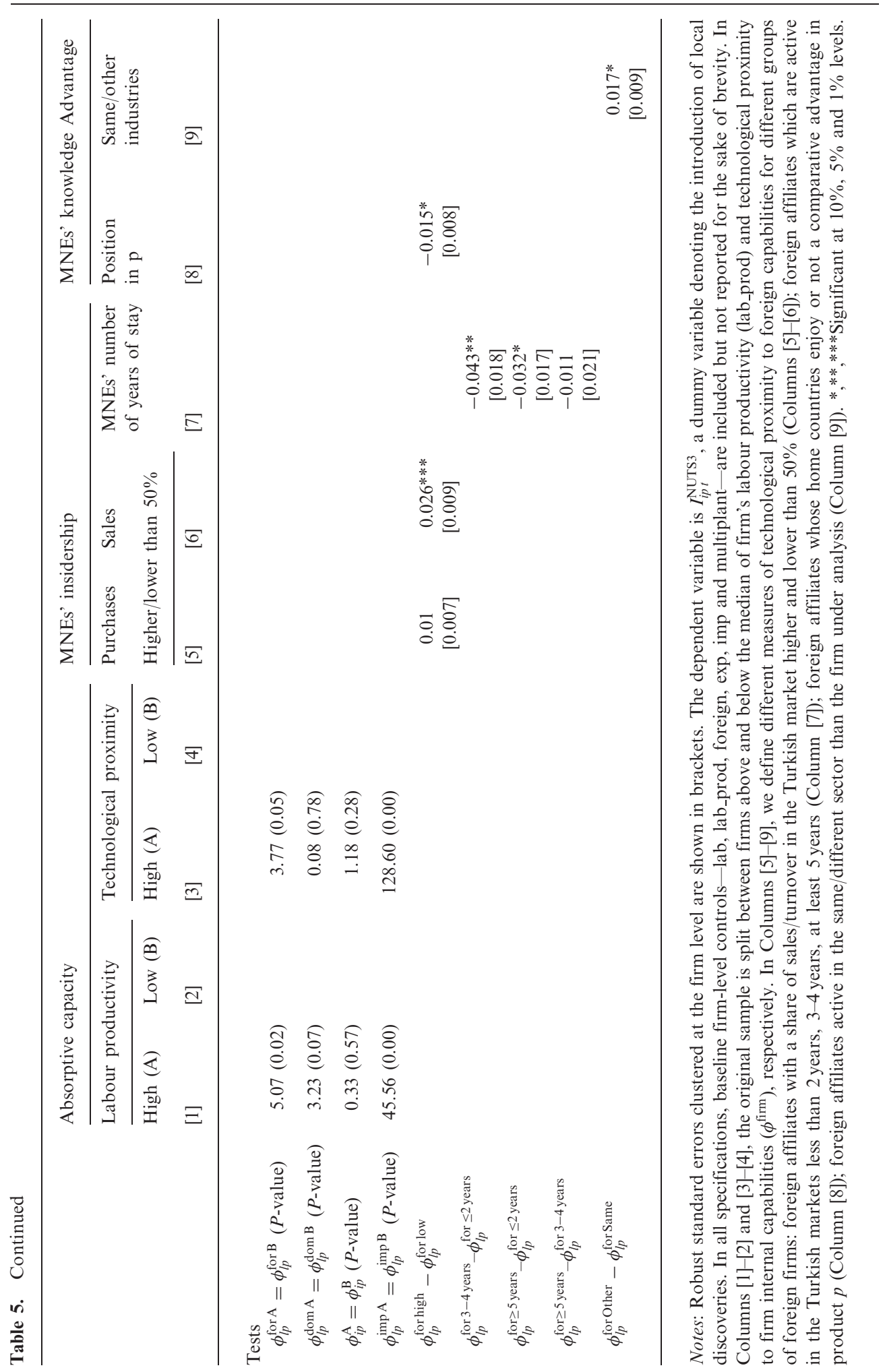

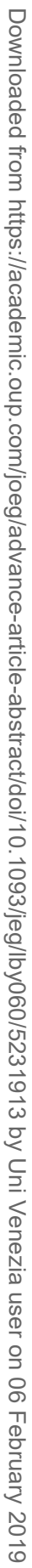


MNEs in the local market. This evidence is in line with previous work on both developed and developing economies (Kokko et al., 1996; Girma and Wakelin, 2001). Then, we propose a further test of the absorptive capacity hypothesis, by splitting firms whose own technological relatedness to the product to introduce, $\phi_{i p}^{\text {firm }}$, is above or below the sample median. Columns [3] and [4] reveal that firms with own internal capabilities that are highly proximate to the product to introduce are the ones that mostly benefit from knowledge transfers by MNEs. Therefore, hypothesis HP2a is corroborated by our data.

In order to assess and measure the extent of insidership of MNEs in the province network, we consider the extent of foreign firms' involvement with the domestic market both in terms of the share of their sales/purchases that is sold/bought in the Turkish market and in terms of the number of presence years in the provincial market (Kiyota et al., 2008; Giroud and Scott-Kennel, 2009). Hence, we measure and test technological relatedness to foreign firms who buy/sell a share of their intermediates/output that is higher/lower than $50 \%-\phi_{l p}^{\text {for high }} / \phi_{l p}^{\text {for low }}$-in the domestic Turkish market. Results (Columns [5] and [6]) imply that there is no difference in the importance of knowledge transfers from foreign affiliates according to their share of purchases in the domestic market, while we find that our baseline findings are mainly driven by relatedness to MNEs' affiliates who sell a non-negligible share of their turnover in the Turkish domestic market. In Column [7], instead, we investigate whether knowledge transfers originate from the activity of MNEs which are characterised by a long-standing presence in the market, proxied by the number of years a firm is present in the SBS dataset. In the table, $\phi_{l p}^{\text {for } \leq 2 \text { years }}, \phi_{l p}^{\text {for } 3-4 \text { years }}$ and $\phi_{l p}^{\text {for } \geq 5 \text { years }}$ measure technological relatedness to foreign firms active in the province since less than 2 years, since 3 or 4 years and since 5 or more years, respectively. The results reveal that the highest coefficient and significance is recorded for related knowledge transfers spilling from foreign firms active in the local market since 3 or 4 years. A significant, although lower, coefficient is also recorded for relatedness to foreign firms active in the province since 5 or more years, while no effect stems from foreign firms whose presence in the provincial market is lower than or equal to 2 years. For knowledge transfers to be effective foreign firms need to be present in the local market since a relevant number of years. All in all, our hypothesis HP2b is confirmed.

Concerning the role of the ownership advantage of foreign firms in affecting the effectiveness of knowledge transfers to local actors, we propose two tests based on the relevance of foreign firms' advantage in the product-specific knowledge creation in the global economy and on the belonging to a similar/different sector of activity with respect to the local firm under analysis.

In Column [8], we investigate whether technologically related knowledge transferred by world product leaders is more effective than knowledge transferred by non-leaders. We therefore distinguish relatedness to products where foreign firms' home countries have a comparative advantage, $\phi_{l p}^{\text {for high }}$, from relatedness to products where they have no comparative advantage, $\phi_{l p}^{\text {for low }} .{ }^{11}$ Results in Column [8] reveal that a larger effect is

11 On the basis of the BACI trade flow database for the pre-sample year 2002, we have calculated RCA indicators by country and product and we have classified as RCA products for a country those goods where the country showed a RCA above 1. Then, we have matched this country-product level information with our country-product level information of foreign firms' products and we have split them into two groups of goods with and without RCA, respectively. 
driven by foreign firms' products whose home country does not enjoy a comparative advantage in the product. This suggests that foreign firms not holding a position as world leaders in the product are more prone to share their knowledge compared with those firms whose products are a reflection of their leadership position.

Finally, in Column [9] we split local foreign firms according to their belonging to the same or a different two-digit industry compared with the industry of the local firm under analysis and we, thus, calculate two measures of technological relatedness to foreign firms active in the same industry and in other industries, $\phi_{l p}^{\text {for Same }}$ and $\phi_{l p}^{\text {for Other }}$, respectively. ${ }^{12}$ The evidence is in favour of a prominent role of technological relatedness from different industries and, again, hints at foreign firms being keen on sharing their product-specific knowledge when the latter does not represent a strategic asset for the MNE. While in this case MNEs typically seek inter-firm partnerships in the local market to cope with global competition, in the case of product specific knowledge representing a strategic asset, they would rather rely on intra-firm coordination for the exploitation of own capabilities and will certainly be reluctant to share knowledge with local firms active in the same sector (Fuller and Phelps, 2018). This seems in line with the hypothesis that foreign firms are willing to preserve their knowledge advantages when interacting with local firms that could exploit it to compete with them. Hence, hypothesis HP2c is also corroborated.

\section{Conclusion}

In this paper, we have investigated the role of intra- and extra-regional product-specific knowledge sources in fostering the introduction of local discoveries. Our empirical evidence on Turkish firms' product space evolution reveals that a firm's probability to introduce a local discovery is significantly favoured by its technological relatedness to co-located foreign firms' production mix. Proximity to imported products in the province and to co-located domestic firms' product baskets does not play, instead, any role, while we corroborate the extant evidence on the relevance of firms' own internal resources. The relative importance of knowledge transfers by co-located foreign and domestic firms is reversed when we look at the introduction of goods new only to the firm and not to the region. More specifically, by investigating the goods' capabilities content as reflected by their complexity measure, it emerges that relatedness to foreign firms favours the introduction of complex goods, while knowledge stemming from colocated domestic firms eases the entry in the production of simpler products. Therefore, our evidence points at two key factors at the basis of the regional structural change: the higher exclusivity of capabilities owned and transferred by MNEs compared with the remaining co-located domestic firms and the fundamental importance of human exchanges and social interactions for tacit knowledge transfers to be effective. We further show that the MNEs' role as technological gatekeepers in the local market is effective when the product-specific knowledge that they share is not a strategic asset for

12 It is worth mentioning that when creating subgroups of foreign firms, some of the groups are undefined for some provinces. As an example, if foreign firms in a province are all active in a sector, then for local firms active in this sector only technological relatedness to foreign firms in the same sector would be defined, while technological relatedness to foreign firms in different sectors would be missing. This explains the lower number of observations in some sub-samples. 
them, when they are insiders in the local market and when local firms have an adequate absorptive capacity.

Our evidence calls into question the treatment of firms co-located in a geographical space as a homogeneous group. On the one hand, while both domestic and foreign entrepreneurs shape the local product space, only knowledge transfers from MNEs allow to extend production possibilities beyond the traditional development trajectories rooted on purely intra-regional capabilities. In this respect, we then shed light on one micro level channel behind the FDI-growth nexus by showing that foreign firms' knowledge transfers can represent a tool for favouring economic development by escaping path dependence. On the other hand, the evidence on the moderating role of local firms' absorptive capacity suggests that only a subset of them is able to reap the benefits spilling from the presence of MNEs in the local market.

Future research should be devoted to overcome the limitations of this work and to explore further avenues of investigation. The validity of our evidence should be tested in further economic contexts to assess the generality of our finding. Also, the role of cultural barriers between MNEs' origin countries in hampering/favouring productspecific knowledge flows should be investigated to further qualify the conditions for effective knowledge transfers. Finally, our analysis has inspected product-specific knowledge flows within manufacturing activities. Nonetheless, highly specialised services are increasingly relevant for goods invention and production. Future work should, then, be devoted to uncover the innovation propulsive role of knowledge flows stemming from related service providers.

\section{Supplementary material}

Supplementary data for this paper are available at Journal of Economic Geography online.

\section{References}

Aghion, P., Howitt, P. (1998) Endogenous Growth Theory. Cambridge (MA): MIT Press.

Anand, J., Delios, A. (2002) Absolute and relative resources as determinants of international acquisitions. Strategic Management Journal, 23: 119-134.

Asheim, B. T., Isaksen, A. (2002) Regional innovation systems: the integration of local 'sticky' and global 'ubiquitous' knowledge. The Journal of Technology Transfer, 27: 77-86.

Balassa, B. (1965) Trade liberalisation and revealed comparative advantage. Journal of Financial Economics, 33: 99-123.

Bathelt, H., Malmberg, A., Maskell, P. (2004) Clusters and knowledge: local buzz, global pipelines and the process of knowledge creation. Progress in Human Geography, 28: 31-56.

Boschma, R. (2005) Proximity and innovation: a critical assessment. Regional Studies, 39: 61-74.

Boschma, R., Frenken, K. (2006) Why is economic geography not an evolutionary science? Towards an evolutionary economic geography. Journal of Economic Geography 6: 273-302.

Boschma, R., Frenken, K. (2011) Technological relatedness and regional branching. In H. Bathelt, M. Feldman and D. Kogler (eds) Beyond Territory: Dynamic Geographies of Knowledge Creation and Innovation, pp. 64-81. Routledge: Taylor and Francis.

Boschma, R., Iammarino, S. (2009) Related varieties, trade linkages, and regional growth in Italy. Economic Geography, 85: 289-311. 
Boschma, R., Minondo, A., Navarro, M. (2013) The emergence of new industries at the regional level in Spain: a proximity approach based on product relatedness. Economic Geography, 89: 29-51.

Breschi, S., Lissoni, F., Malerba, F. (2003) Knowledge relatedness in firm technological diversification. Research Policy, 32: 69-87.

Cantwell, J. (2017) Innovation and international business. Industry and Innovation, 24: 41-60.

Cantwell, J., Iguchi, C. (2005) Effects of backward linkages to local suppliers' development path: the case of the Malaysian electrical and electronics industry. In: A. Giroud, D. Yang and A. Mohr (eds) Multinationals and Asia: Organizational and Institutional Relationships, pp. 5471. London: Routledge.

Castaldi, C., Frenken, K., Los, B. (2015) Related variety, unrelated variety and technological breakthroughs: an analysis of US state-level patenting. Regional Studies, 49: 767-781.

Coe, N. M., Yeung, H. W.-c. (2015) Global Production Networks: Theorizing Economic Development in an Interconnected World. Number 9780198703914 in OUP Catalogue. Oxford University Press.

Cohen, W., Levinthal, D. (1990) Absorptive capacity. A new perspective on learning and innovation. Admistrative Science Quarterly, 35: 128-152.

Colantone, I., Crinò, R. (2014) New imported inputs, new domestic products. Journal of International Economics, 92: 147-165.

Coviello, N. (2006) The network dynamics of international new ventures. Journal of International Business Studies, 37: 713-731.

Danneels, E. (2002) The dynamics of product innovation and firm competences. Strategic Management Journal, 23: 1095-1121.

Ernst, D., Kim, L. (2002) Global production networks, knowledge diffusion, and local capablity formation. Research Policy, 31: 1417-1429.

Frenken, K., Van Oort, F., Verburg, T. (2007) Related variety, unrelated variety and regional economic growth. Regional Studies, 41: 685-697.

Fuller, C., Phelps, N. A. (2018) Revisiting the multinational enterprise in global production networks. Journal of Economic Geography, 18: 139-161.

Gaulier, G., Zignago, S. (2010) BACI: international trade database at the product-level. The 1994-2007 version. Working paper, 2010-23, CEPII.

Gertler, M. S. (2003) Tacit knowledge and the economic geography of context, or the undefinable tacitness of being (there). Journal of Economic Geography, 3: 75-99.

Girma, S., Wakelin, K. (2001) Regional underdevelopment: is FDI the solution? A semiparametric analysis. CEPR Discussion Papers 2995, C.E.P.R. Discussion Papers.

Giroud, A. (2007) MNEs vertical linkages: the experience of Vietnam after Malaysia. International Business Review, 16: 159-176.

Giroud, A., Jindra, B., Marek, P. (2012) Heterogeneous FDI in transition economies - a novel approach to assess the developmental impact of backward linkages. World Development, 40: 2206-2220.

Giroud, A., Mirza, H. (2006) Multinational enterprises and local input linkages in Southeast Asia. Transnational Corporations, 15: 1-32.

Giroud, A., Scott-Kennel, J. (2009) MNE linkages in international business: a framework for analysis. International Business Review, 18: 555-566.

Giuliani, E. (2011) The role of technological gatekeepers in the growth of industrial clusters: evidence from Chile. Regional Studies, 45: 1329-1348.

Grabher, G. (1993) The weakness of strong ties: the lock-in of regional development in the Ruhr area. In G. Grabher (ed.) The Embedded Firm, pp. 255-277. London: Routledge.

Graf, H. (2011) Gatekeepers in regional network of innovators. Cambridge Journal of Economics, 35: 173-198.

Haskel, J. E., Pereira, S. C., Slaughter, M. J. (2007) Does inward foreign direct investment boost the productivity of domestic firms? The Review of Economics and Statistics, 89: 482-496.

Hausmann, R., Hidalgo, C. A. (2009) The building blocks of economic complexity. Proceedings of the National Academy of the United States of America, 106: 10570-10575.

Hausmann, R., Neffke, F. (2016) The workforce of pioneer plants of firms and entrepreneurs in regional diversification. Faculty Research Working Paper Series. Harvard Kennedy School, Harvard University. 
Hidalgo, C. (2009) The dynamics of economic complexity and the product space over a 42 year period. Working papers 189. Center for International Development, Harvard University.

Hidalgo, C. A., Klinger, B., Barabasi, A.-L., Hausmann, R. (2007) The product space conditions the development of nations. Science, 317: 482-487.

Howells, J. (2012) The geography of knowledge: never so close but never so apart. Journal of Economic Geography, 12: 1003-1020.

International Monetary Fund. (1993) Balance of Payments Manual. 5th edn edn. Washington (DC): IMF.

Javorcik, B. (2008) Can survey evidence shed light on spillovers from foreign direct investment? World Bank Research Observer, 23: 139-159.

Javorcik, B., Lo Turco, A., Maggioni, D. (2017) New and improved: does FDI boost production complexity in host countries? Economic Journal, 128: 2507-2537.

Jindra, B., Giroud, A., Scott-Kennel, J. (2009) Subsidiary roles, vertical linkages and economic development: lessons from transition economies. Journal of World Business, 44: 167-179.

Johanson, J., Vahlne, J. (2009) The Uppsala internationalization process model revisited: from liability of foreignness to liability of outsidership. Journal of International Business Studies, 40: 1411-1431.

Kim, L. (1998) Crisis construction and organizational learning: capability building in catching-up at Hyundai motor. Organization Science, 9: 506-521.

Kiyota, K., Matsuura, T., Urata, S., Wei, Y. (2008) Reconsidering the backward vertical linkages of foreign affiliates: evidence from Japanese multinationals. World Development, 36: 1398 1414.

Kogut, B. (2000) The network as knowledge: generative rules and the emergence of structure. Strategic Management Journal, 21: 405-425.

Kokko, A., Tansini, R., Zejan, M. (1996) Productivity spillovers from FDI in the Uruguayan manufacturing sector. Journal of Development Studies, 32: 602-611.

Lambooy, J., Boschma, R. (2001) Evolutionary economics and regional policy. Annals of Regional Science, 35: 113-133.

Lo Turco, A., Maggioni, D. (2016) On firms' product space evolution: the role of firm and local product relatedness. Journal of Economic Geography, 16: 975-1006.

Lorenzen, M., Mudambi, R. (2013) Clusters, connectivity and catch-up: bollywood and Bangalore in the global economy. Journal of Economic Geography 13: 501-534.

Markusen, J., Venables, A. J. (2000) The theory of endowment, intra-industry and multi-national trade. Journal of International Economics, 52: 209-234.

Maskell, P., Malmberg, A. (1999) Localised learning and industrial competitiveness. Cambridge Journal of Economics, 23: 167-186.

Miguelez, E., Moreno, R. (2017) Relatedness, external linkages and regional innovation in Europe. Regional Studies, 52: 688-701.

Miguélez, E., Moreno, R. (2015) Knowledge flows and the absorptive capacity of regions. Research Policy, 44: 833-848.

Morrison, A. (2008) Gatekeepers of knowledge within industrial districts: who they are, how they interact. Regional Studies, 42: 817-835.

Morrison, A., Rabellotti, R., Zirulia, L. (2013) When do global pipelines enhance the diffusion of knowledge in clusters? Economic Geography, 89: 77-96.

Mudambi, R. (2008) Location, control and innovation in knowledge-intensive industries. Journal of Economic Geography, 8: 699-725.

Munari, F., Sobrero, M., Malipiero, A. (2012) Absorptive capacity and localized spillovers: focal firms as technological gatekeepers in industrial districts. Industrial and Corporate Change, 21: $429-462$.

Neffke, F., Hartog, M., Boschma, R., Henning, M. (2014) Agents of structural change: the role of firms and entrepreneurs in regional diversification. Working paper. Center for International Development at Harvard University.

Neffke, F., Henning, M. (2013) Skill relatedness and firm diversification. Strategic Management Journal, 34: 297-316.

Neffke, F., Henning, M., Boschma, R. (2011) How do regions diversify over time? Industry relatedness and the development of new growth paths in regions. Economic Geography, 87: $237-265$. 
Nooteboom, B. (2000) Learning and Innovation in Organizations and Economies. Oxford: Oxford University Press.

OECD. (2008) OECD Benchmark Definition of Foreign Direct Investment. OECD.

Poon, J. P., Kedron, P., Bagchi-Sen, S. (2013) Do foreign subsidiaries innovate and perform better in a cluster? A spatial analysis of Japanese subsidiaries in the US. Applied Geography, 44: 33-42.

Porter, M. (2003) The economic performance of regions. Regional Studies, 37: 545-546.

Rodríguez-Pose, A., Comptour, F. (2012) Do clusters generate greater innovation and growth? An analysis of European regions. The Professional Geographer, 64: 211-231.

Shane, S. (2000) Prior knowledge and the discovery of entrepreneurial opportunities. Organisation Science, 11: 367-472.

Shefer, D., Frenkel, A. (1998) Local milieu and innovations: some empirical results. The Annals of Regional Science, 32: 185-200.

UNCTAD. (2003) FDI policies for development: national and international perspectives. World Investment Report, United Nations Conference on Trade and Development.

Wang, C. C., Guo, Y. (2017) Local innovativeness and knowledge spillovers of indigenous firms on foreign firms: evidence from China's ICT industry. The Professional Geographer, 69: 117125.

Wang, C. C., Wu, A. (2016) Geographical FDI knowledge spillover and innovation of indigenous firms in China. International Business Review, 25: 895-906.

Zaheer, S. (1995) Overcoming the liability of foreignness. Academy of Management Journal, 38: 341-363.

Zahra, S. A., George, G. (2002) Absorptive capacity: a review, reconceptualization, and extension. The Academy of Management Review, 27: 185-203.

Zhu, S., Hey, C., Zhou, Y. (2017) How to jump further and catch up? Path-breaking in an uneven industry space. Journal of Economic Geography, 17: 521-545. 